\title{
Effects of nitrogen sources on cell growth and biochemical composition of marine chlorophyte Tetraselmis sp. for lipid production
}

\author{
Garam Kim, Ghulam Mujtaba and Kisay Lee* \\ Department of Environmental Engineering and Energy, Myongji University, Yongin 17058, Korea
}

Nitrogen is one of the most critical nutrients affecting cell growth and biochemical composition of microalgae, ultimately determining the lipid or carbohydrate productivity for biofuels. In order to investigate the effect of nitrogen sources on the cell growth and biochemical composition of the marine microalga Tetraselmis sp., nine different $\mathrm{N}$ sources, including $\mathrm{NaNO}_{3}, \mathrm{KNO}_{3}, \mathrm{NH}_{4} \mathrm{NO}_{3}, \mathrm{NH}_{4} \mathrm{HCO}_{3}, \mathrm{NH}_{4} \mathrm{Cl}, \mathrm{CH}_{3} \mathrm{COONH}_{4}$, urea, glycine, and yeast extract were compared at the given concentration of $8.82 \mathrm{mM}$. Higher biomass concentration was achieved under organic nitrogen sources, such as yeast extract $\left(2.23 \mathrm{~g} \mathrm{~L}^{-1}\right)$ and glycine $\left(1.62 \mathrm{~g} \mathrm{~L}^{-1}\right)$, compared to nitrate- $\left(1.45 \mathrm{~g} \mathrm{~L}^{-1}\right)$ or ammonium- $\mathrm{N}\left(0.98 \mathrm{~g} \mathrm{~L}^{-1}\right)$. All ammonium sources showed an inhibition of cell growth, but accumulated higher lipids, showing a maximum content of $28.3 \%$ in ammonium bicarbonate. When Tetraselmis sp. was cultivated using yeast extract, the highest lipid productivity of 36.0 $\mathrm{mg} \mathrm{L}^{-1} \mathrm{~d}^{-1}$ was achieved, followed by glycine $21.5 \mathrm{mg} \mathrm{L}^{-1} \mathrm{~d}^{-1}$ and nitrate $19.9 \mathrm{mg} \mathrm{L}^{-1} \mathrm{~d}^{-1}$. Ammonium bicarbonate resulted in the lowest lipid productivity of $14.4 \mathrm{mg} \mathrm{L}^{-1} \mathrm{~d}^{-1}$. The major fatty acids in Tetraselmis sp. were palmitic, oleic, linoleic and linolenic acids, regardless of the nutritional compositions, indicating the suitability of this species for biodiesel production.

Key Words: biochemical composition; fatty acid profile; mixotrophic culture; nitrogen sources; Tetraselmis

\section{INTRODUCTION}

Marine microalgae have great potential as feedstock for biofuels, such as biodiesel and bioethanol. Microalgal biomass and biofuels production are affected by a variety of physicochemical factors such as nutrients, light supply, temperature, $\mathrm{pH}$ and salinity (Kim et al. 2014, Yen et al. 2014, Bartley et al. 2016). Particularly among various nutritional factors, nitrogen is considered one of the most critical nutrient for growth, since it is a constituent in all structural and functional proteins such as peptides, enzymes, chlorophylls, energy transfer molecules, and genetic materials in algal cells (Cai et al. 2013, Hu 2013). The concentration of nitrogen in culture medium consider- ably affects both cell growth rate and biochemical compositions of microalgae (Wang et al. 2013), and numerous studies have shown that when the nitrogen is limited in culture medium, microalgae slow down cell growth rate and increase their lipid or carbohydrate content, reducing protein synthesis (Ho et al. 2014).

Most microalgae are able to utilize various forms of nitrogen, including nitrate, nitrite, ammonium and organic nitrogen sources such as urea (Becker 1994); each nitrogen source is first reduced to the ammonium form and assimilated into amino acids through a variety of pathways (Cai et al. 2013). Typically, ammonium was known
(7) \$ This is an Open Access article distributed under the terms of the Creative Commons Attribution Non-Commercial License (http://creativecommons.org/licenses/by-nc/3.0/) which permits unrestricted non-commercial use, distribution, and reproduction in any medium, provided the original work is properly cited.
Received March 15, 2016, Accepted August 18, 2016

* Corresponding Author

E-mail: kisay@mju.ac.kr

Tel: +82-31-330-6689, Fax: +82-31-336-6336 
to be preferred by many microalgae, as it requires less energy for assimilating into amino acids, but some microalgae such as Botryococcus braunii and Dunaliella tertiolecta prefer nitrate over ammonium for growth (Chen et al. 2011, Ruangsomboon 2015). Some Chlorella spp. also prefer nitrate rather than ammonium for growth, and they also effectively utilize organic nitrogen sources including urea, glycine, yeast extract (YE) and peptone (Li et al. 2013, Muthuraj et al. 2014). Depending on the source of nitrogen, biochemical composition can also be changed; for example, protein content of Dunaliella sali$n a$ was 2-fold higher under ammonium than nitrate supplementation (Norici et al. 2002), while the lipid content of Chlorella sorokiniana was over 2-times higher under ammonium than urea or nitrate supplementation (Wan et al. 2012). Since the favorable nitrogen source for growth is different from species to species, and the biochemical composition also can be changed by the supplemented nitrogen sources, it is required to compare various nitrogen sources and select the most appropriate one for each species in order to maximize the productivity of the target product, such as lipid for biodiesel and carbohydrate for bioethanol.

In this study, a marine microalga, Tetraselmis sp., was chosen for lipid production, as it shows active cell growth in a wide range of salinity and low temperature, thus showing a feasibility of cultivation with natural seawater on-site for the biodiesel production (Lee et al. 2015, Kim et al. 2016b, 2016c). The effects of different nitrogen sources including nitrate, ammonium, and organic nitrogen on the cell growth, and the biochemical composition of Tetraselmis sp. were investigated. Also, the microalgal biomass was converted to fatty acid methyl esters (FAME) biodiesel, and the fatty acid profile was analyzed for estimating the effect on the consequent biodiesel properties.

\section{MATERIALS AND METHODS}

\section{Microalgal strain and culture conditions}

Green marine alga Tetraselmis sp. Ganghwa (KCTC 12236BP, Korean Collection for Type Cultures, Korea Research Institute of Bioscience and Biotechnology) was provided by the Marine Bioenergy Research Center in Korea (Lee et al. 2015). The algal cells were cultivated in artificial seawater (ASW) enriched F/2 nutrients with modification of $\mathrm{NaNO}_{3}$ concentration from 0.075 to 0.75 $\mathrm{g} \mathrm{L}^{-1}$ (Guillard 1975).

Tetraselmis cells were inoculated in conical-ended cy- lindrical photobioreactors (PBRs) with a working volume of $500 \mathrm{~mL}$ ASW enriched with modified F/2 nutrients, containing different nitrogen sources. Initial cell concentration was adjusted to about $0.5-0.6 \mathrm{~g} \mathrm{~L}^{-1}$ in all experiments, by measuring the optical density at $680 \mathrm{~nm}\left(\mathrm{OD}_{680}\right.$ 0.9-1.0) based on the calibration curve between $\mathrm{OD}_{680}$ and cell concentration $\left(\mathrm{g} \mathrm{L}^{-1}\right)$. Ambient air was provided through the bottom of the PBRs, and the air was filtered using $0.2 \mu \mathrm{m}$ polytetrafluorethylene membrane filters before entering to the PBRs. A constant aeration rate of $0.2 \mathrm{vvm}$ was maintained using gas flow meters (RateMaster; Dwyer, Michigan City, IN, USA). Light was supplied continuously for $24 \mathrm{~h}$ with a constant intensity of 100-120 $\mathrm{mmol} \mathrm{m}^{-2} \mathrm{~s}^{-1}$ using fluorescent lamps (FL20SD/19; Kumho, Seoul, Korea) at both sides of PBRs. Experiments were conducted in a separated cultivation room within temperature of $20-25^{\circ} \mathrm{C}$.

In order to investigate the influence of different nitrogen sources on the cell growth and biochemical composition of Tetraselmis sp., sodium nitrate $\left(\mathrm{NaNO}_{3}, 0.750\right.$ $\left.\mathrm{g} \mathrm{L}^{-1}\right)$ in $\mathrm{F} / 2$ medium was replaced by different nitrogen sources, including potassium nitrate $\left(\mathrm{KNO}_{3}, 0.892 \mathrm{~g} \mathrm{~L}^{-1}\right)$, ammonium nitrate $\left(\mathrm{NH}_{4} \mathrm{NO}_{3}, 0.353 \mathrm{~g} \mathrm{~L}^{-1}\right)$, ammonium bicarbonate $\left(\mathrm{NH}_{4} \mathrm{HCO}_{3}, 0.697 \mathrm{~g} \mathrm{~L}^{-1}\right)$, ammonium chloride $\left(\mathrm{NH}_{4} \mathrm{Cl}, 0.472 \mathrm{~g} \mathrm{~L}^{-1}\right)$, ammonium acetate $\left(\mathrm{CH}_{3} \mathrm{COONH}_{4}\right.$, $\left.0.680 \mathrm{~g} \mathrm{~L}^{-1}\right)$, urea $\left(\mathrm{CO}\left(\mathrm{NH}_{2}\right)_{2}, 0.265 \mathrm{~g} \mathrm{~L}^{-1}\right)$, glycine $\left(\mathrm{NH}_{2} \mathrm{CH}-\right.$ ${ }_{2} \mathrm{COOH}, 0.662 \mathrm{~g} \mathrm{~L}^{-1}$ ), and YE. Initial nitrogen concentration was the same, at $8.82 \mathrm{mM}\left(123.5 \mathrm{mg} \mathrm{N} \mathrm{L}^{-1}\right)$.

\section{Measurement of cell growth}

Microalgal cell growth was estimated by measuring $\mathrm{OD}_{680}$ and $\mathrm{OD}_{750}$ using a UV/VIS spectrophotometer (DR4000U; Hach, Loveland, CO, USA). Cell dry weight (CDW) was measured using GF/F filters $(0.7 \mu \mathrm{m}$ pore size; Whatman, Maidstone, UK) after removing salts in the medium by centrifugation. Algal cells were washed with $0.5 \mathrm{M}$ ammonium bicarbonate solution and the supernatant was discarded after centrifugation to avoid interference from salts in the ASW (Zhu and Lee 1997). Filters were dried at $80^{\circ} \mathrm{C}$ for $1 \mathrm{~h}$ and stored in a desiccator. Biomass productivity was calculated dividing the difference between CDW at the start and at the end of the experiment, by elapsed time.

\section{Determination of nitrogen concentration}

Nitrate concentrations of $\mathrm{NaNO}_{3}, \mathrm{KNO}_{3}$ and $\mathrm{NH}_{4} \mathrm{NO}_{3}$ were determined according to Ultraviolet spectrophotometric screening method $\left(4500-\mathrm{NO}_{3}{ }^{-}\right.$B) (American Public 
Health Association 1995). Ammonium concentrations of $\mathrm{NH}_{4} \mathrm{NO}_{3}, \mathrm{NH}_{4} \mathrm{HCO}_{3}, \mathrm{NH}_{4} \mathrm{Cl}$, and $\mathrm{CH}_{3} \mathrm{COONH}_{4}$ were measured using Ammonia Test Kits (C-Mac, Daejeon, Korea) applying Nessler Method (4500- $\mathrm{NH}_{3} \mathrm{~B} \& \mathrm{C}$ ) (American Public Health Association 1995). Organic nitrogen concentrations of urea, glycine and YE were determined according to Persulfate method (4500-N C) (American Public Health Association 1995). Initial nitrogen concentrations in all experiments were double checked using TN Test Kits (C-Mac), with relative standard deviation (SD) was 0.77 .

\section{Analyses for lipid, carbohydrate, and protein content}

Algal cells were dried overnight in a vacuum oven at $40^{\circ} \mathrm{C}$, and completely pulverized using a mortar and pestle for analyzing lipid, carbohydrate and protein content. Lipid content was gravimetrically determined after extracting lipids using a mixture solution of chloroform and methanol (Bligh and Dyer 1959). Lipid productivity was calculated dividing the difference in lipid concentration at the start and at the end of the experiment, by elapsed time. Carbohydrate content was quantified according to the modified phenol-sulfuric acid method (Dubois et al. 1956) and protein content was measured by the Lowry method (Lowry et al. 1951).

\section{Transesterification and FAME analysis}

Moisture-free biomass samples were prepared by drying algal cells in a vacuum oven at $40^{\circ} \mathrm{C}$ overnight, and acid-catalyzed transesterification was performed as described by Van Wychen et al. (2013). Composition of fatty acids was analyzed using GC-FID (YL6500; Younglin Instrument, Anyang, Korea) equipped with HP-INNOWAX capillary column (Agilent 19091N-213; Agilent Technologies, Palo Alto, CA, USA). FAME mixture (C8:0-C24:0; Sigma Aldrich \#18918; Sigma Aldrich, St. Louis, MO, USA) was used as a standard FAME, and each fatty acid was determined by the retention time of standard components. Gas chromatography (GC) analysis was performed with the following conditions: sample injection volume was 1 $\mu \mathrm{L}$ at $10: 1$ split ratio, inlet temperature was $260^{\circ} \mathrm{C}$, carrier gas was helium with a constant flow of $1.2 \mathrm{~mL} \mathrm{~min}$ ${ }^{1}$, oven temperature was initially held at $140^{\circ} \mathrm{C}$ for $5 \mathrm{~min}$, increased at a rate of $4^{\circ} \mathrm{C} \mathrm{min}^{-1}$ up to $240^{\circ} \mathrm{C}$ and held for $10 \mathrm{~min}$. Detector temperature was $260^{\circ} \mathrm{C}$, detector gases were hydrogen, $35 \mathrm{~mL} \mathrm{~min}^{-1}$; air zero, $300 \mathrm{~mL} \mathrm{~min}^{-1}$; and helium, $20 \mathrm{~mL} \mathrm{~min}^{-1}$. GC analysis for each sample was conducted in triplicate.

\section{Statistical analysis}

All experiments were performed in duplicates except for FAME analysis, which was performed in triplicate. Data are presented as mean \pm SD. Statistical analysis was done using one-way analysis of variance (ANOVA) in SPSS ver. 22.0 (IBM Co., Armonk, NY, USA). p-values less than 0.05 were considered statistically significance.

\section{RESULTS AND DISCUSSION}

\section{Cell growth under different nitrogen sources}

We found that marine microalga Tetraselmis sp. efficiently utilize organic nitrogen (particularly $\mathrm{YE}$ and to a lesser degree glycine and urea) and nitrate $\left(\mathrm{NaNO}_{3}\right.$ and $\mathrm{KNO}_{3}$ ) for the growth, but not ammonium $\left(\mathrm{NH}_{4} \mathrm{NO}_{3}\right.$, $\mathrm{NH}_{4} \mathrm{HCO}_{3}, \mathrm{NH}_{4} \mathrm{Cl}$, and $\mathrm{CH}_{3} \mathrm{COONH}_{4}$ ) (Fig. 1A). Cell concentration with $\mathrm{YE}$ increased rapidly within 2 days, and reached the highest value of $2.23 \mathrm{~g} \mathrm{~L}^{-1}$ after 10 days. Glycine showed the second highest cell concentration of 1.62 $\mathrm{g} \mathrm{L}^{-1}$, followed by potassium nitrate $\left(1.52 \mathrm{~g} \mathrm{~L}^{-1}\right)$, sodium nitrate $\left(1.48 \mathrm{~g} \mathrm{~L}^{-1}\right)$, and urea $\left(1.39 \mathrm{~g} \mathrm{~L}^{-1}\right)$. However, in all cultures supplemented with ammonium, cell growth inhibition was observed, resulting in an even lower cell concentration than that observed in nitrogen deficient culture.

Despite the inhibition of cell growth, the remaining $\mathrm{N}$ concentrations in medium with ammonium chloride and ammonium acetate showed a faster decrease than that in medium with other $\mathrm{N}$ sources (Fig. 1B). This was probably due to the volatilization of ammonia, and not due to the $\mathrm{N}$ assimilation by microalgal cells. All ammonia exist in the ammonium form $\left(\mathrm{NH}_{4}{ }^{+}\right)$under acidic conditions below $\mathrm{pH}$ 7; however, ammonium ions $\left(\mathrm{NH}_{4}{ }^{+}\right)$are converted to ammonia $\left(\mathrm{NH}_{3}\right)$ under aeration at $\mathrm{pH}$ above 7 , and the ratio of $\mathrm{NH}_{3}$ increases with further increase in $\mathrm{pH}$ (Konig et al. 1987). Thus, there is a high probability of loss of ammonia due to the high $\mathrm{pH}$ around 8.5-9.5 (Fig. 1C). According to previous studies, ammonia stripping was readily caused in an aerated or stirred culture system with increasing $\mathrm{pH}$, which resulted from photosynthetic activity of microalgae (Huang et al. 2012, Cai et al. 2013). Therefore, it seems that the nitrogen consumption by microalgal cells was the largest in medium with YE and not ammonium, as the cell growth rate supports this (Fig. 1A).

Although YE was the fastest consumed nitrogen source by Tetraselmis cells, it seems that the achieved highest cell growth rate is not merely due to the nitrogen, since the $\mathrm{YE}$ 



Fig. 1. Influence of different nitrogen sources on cell growth (A), nitrogen concentration remaining in the medium (B) and $\mathrm{pH}(\mathrm{C})$ with initial $\mathrm{N}=8.82 \mathrm{mM}=123.5 \mathrm{mg} \mathrm{N} \mathrm{L}^{-1}$.

also contains various other compounds such as amino acids, peptides, vitamins and carbohydrate. Tetraselmis sp. seemingly utilizes both nitrogen and organic compounds in YE through mixotrophic metabolism, and consequently the cell growth was more stimulated. While the initial nitrogen concentration was the same in all cultures, the initial concentration of total carbon in the medium with
YE was about 2.5 times higher than that in medium with inorganic $\mathrm{N}$ sources, and it was rapidly consumed during the exponential cell growth over 2 days (data not shown). It is known that not every microalga can utilize YE as both nitrogen and organic carbon sources efficiently. Gu et al. (2015) reported that when supplying the same concentration of YE, a freshwater microalga Scenedesmus acutus actively utilized $\mathrm{YE}$ for growth, resulting in a very high cell concentration, up to $10.4 \mathrm{~g} \mathrm{~L}^{-1}$. However, Chlorella and Nannochloropsis species showed an insignificant increase in cell concentration. The results indicate that mixotrophic cultivation using YE would be more advantageous for some species including Tetraselmis sp., as seen in the present study.

Glycine, which showed the second highest cell growth rate, forms the dissolved free amino acids in culture medium that can be readily utilized by microalgae (Kumar et al. 2014). Some microalgae species, such as Chlorella, were reported to produce a significantly high cell concentration when glycine was the nitrogen source (Li et al. 2013, Kumar et al. 2014, Muthuraj et al. 2014). Urea, another organic nitrogen source, is relatively cheaper than other nitrogen sources, and can also be easily utilized after being degraded to ammonium and bicarbonate via urease in most microalgae (Solomon and Gilbert 2008). Tetraselmis sp. also grew well in urea supplementation, but the final cell concentration and biomass productivity were a little bit lower than seen with nitrate supplementation. Conversely, a marine microalga Nannochloropsis salina, was reported to show a clear preference to urea over nitrate or ammonium for its growth (Campos et al. 2014). Isochrysis galbana was also found to produce the highest cell concentration in urea rather than nitrate or nitrite (Fidalgo et al. 1998). These results indicate that the preference for nitrogen source and the ability of nitrogen utilization are different from species to species.

It is well known that ammonium is generally preferred by many microalgae rather than nitrate or nitrite. Since ammonium is the reduced form of nitrogen, it can be directly assimilated into amino acids inside the cells, whereas nitrate or nitrite must first be reduced to ammonium prior to its utilization (Podevin et al. 2015). However, in the present study, it was found that nitrate is more favorable for the growth of Tetraselmis cells, showing approximately a 2 -fold higher biomass productivity in nitrate compared to ammonium (Fig. 1A). Many other microalgae were also reported to clearly prefer nitrate over ammonium for growth, such as D. tertiolecta, I. galbana, Neochloris oleoabundans, C. sorokiniana, and Botryococcus braunii (Li et al. 2008, 2013, Chen et al. 2011, Roop- 
narain et al. 2015, Ruangsomboon 2015).

Under ammonium supplementation, Tetraselmis cells showed cell growth inhibition, indicating that it was toxic to the cell growth, at the given concentration of $8.82 \mathrm{mM}$. The inhibitory level of ammonium on cell growth is different, depending on the microalgal species. A marine microalga $D$. tertiolecta was reported to show cell growth inhibition at ammonium concentrations above $10 \mathrm{mM}$ (Chen et al. 2011), and $15 \mathrm{mM}$ was reported to inhibit the growth of a blue-green alga Arthrospira platensis (Ferreira et al. 2010), whereas even low levels of $1.2 \mathrm{mM}$ were reported to be lethal for some marine algae (Lourenço et al. 2002). The inhibitory effect on cell growth is attributed to the fact that the excessive transport of ammonium to the cells can hinder the formation of ATP in the chloroplast, leading to the inhibition of photosynthesis (Ramanna et al. 2014). While the nitrate transport is highly regulated in algal cells, ammonium influx is not easily controlled, particularly when the extracellular ammonium level is high (Norici et al. 2002). Also, in some cases, oversaturation of ammonium in the medium can significantly decreased the $\mathrm{pH}$ by releasing $\mathrm{H}^{+}$ions, consequently inhibiting cell growth and even causing cell lysis (Li et al. 2013, Wu et al. 2013).

In the nitrogen deficient culture, Tetraselmis cells sustained the growth, resulting in a higher cell concentration than that in ammonium culture. Some species such as $S$. acutus, Chlorella vulgaris, Nannochloropsis sp., and $N$. oleoabundans were also reported to grow well in nitrogen deficient conditions utilizing their intracellular nitrogen reserves, such as pigment protein molecules (Li et al. 2008, Gu et al. 2015). Blue-green alga A. platensis was also known to degrade phycocyanin, and used it as a nitrogen source under nitrogen-limited conditions (Sassano et al. 2007).

\section{Changes in biochemical composition and lipid productivity}

At the start of cultivation, Tetraselmis cells were composed of approximately 15\% lipid, 42\% carbohydrate, and $24 \%$ protein, but the composition was significantly changed depending on the supplemented nitrogen sources as well as cultivation time (Figs $2 \& 3$ ).

All cultures except $\mathrm{N}$ deficient one, showed an increasing trend in lipid content as the cultivation time elapsed, and the degree of increase in lipid content was very different, depending on the supplied N sources (Fig. 2A). In the cultures supplemented with ammonium, the cells mostly showed higher lipid contents than those with other $\mathrm{N}$
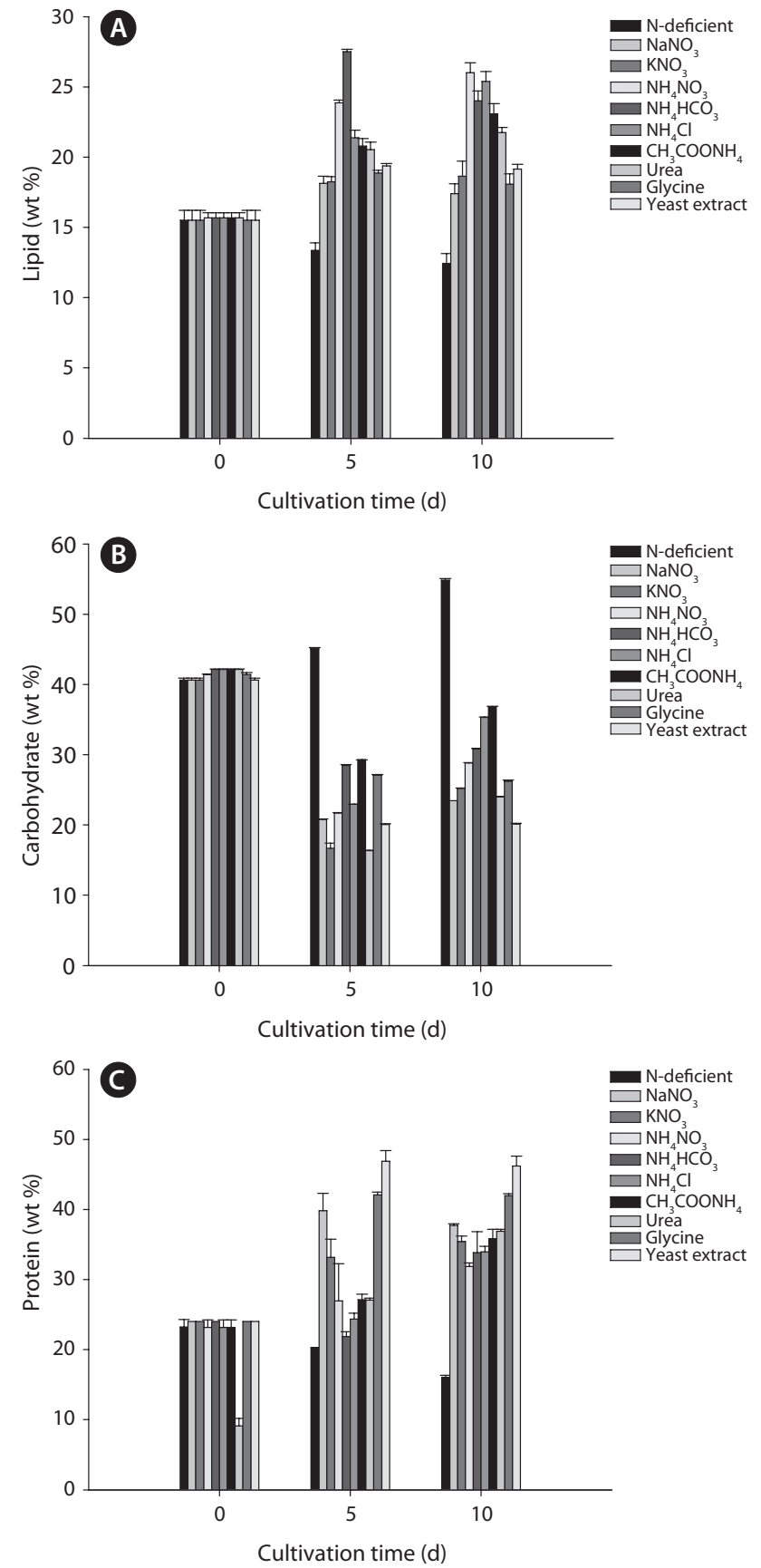

Fig. 2. Influence of different nitrogen sources on cellular contents of lipid (A), carbohydrate (B), and protein (C) with initial $\mathrm{N}=8.82 \mathrm{mM}$ $=123.5 \mathrm{mg} \mathrm{N} \mathrm{L}^{-1}$.

sources. Particularly when supplemented with ammonium bicarbonate, the lipid content increased from 15.7 to $26.8 \%$ within 2 days and reached a maximum of $28.1 \%$ after 7 days. In cultures supplemented with nitrate and organic-N, the lipid content moderately increased up to $18.1-21.8 \%$ on the 10th day, while in the culture which was not supplied any nitrogen source, a continuous de- 


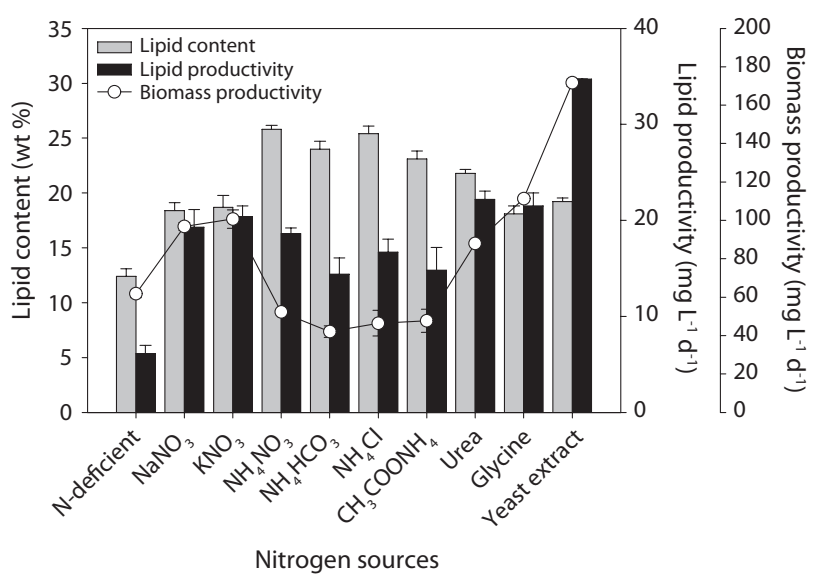

Fig. 3. Comparison of biomass productivity, cellular lipid content, and lipid productivity under different nitrogen sources on the final day of cultivation.

crease in lipid content was seen, resulting in the lowest lipid content and lipid productivity on the final day (Fig. 3). Although higher lipid content was obtained from the cultures with ammonium supplementation, the lipid productivity (16.1 $\left.\mathrm{mg} \mathrm{L}^{-1} \mathrm{~d}^{-1}\right)$ was lower than that of nitrate- $\left(19.9 \mathrm{mg} \mathrm{L}^{-1} \mathrm{~d}^{-1}\right)$ or organic-N $\left(34.7 \mathrm{mg} \mathrm{L}^{-1} \mathrm{~d}^{-1} \mathrm{YE}\right.$, $22.2 \mathrm{mg} \mathrm{L}^{-1} \mathrm{~d}^{-1}$ urea, and $21.5 \mathrm{mg} \mathrm{L}^{-1} \mathrm{~d}^{-1}$ glycine) supplementation due to a significantly lower biomass production, resulting from the cell growth inhibition due to ammonium. Similarly, I. galbana and C. sorokiniana were reported to accumulate lipids when supplemented with ammonium as a nitrogen source rather than nitrate or urea, but the final biomass concentrations were very low due to the inhibition of cell growth by ammonium (Wan et al. 2012, Roopnarain et al. 2015). In the present study, the lipid productivity was higher in cultures with organic$\mathrm{N}$ followed by nitrate, owing to the high biomass productivity, indicating the importance of both high biomass concentration and cellular lipid content of microalgae for enhancing lipid production (Kim et al. 2016b). Among all nine nitrogen sources, YE resulted in the highest lipid productivity, followed by urea, glycine, and nitrate; all the four ammonium sources were found to be inappropriate due to their inhibitory effect on cell growth.

The changes in carbohydrate and protein content of Tetraselmis cells mostly showed opposite trends when evaluated in nitrogen deficient or sufficient conditions (Fig. 2B \& C). In the $\mathrm{N}$ deficient culture, carbohydrate content increased considerably and reached up to $55 \%$ on the final day of cultivation, but protein content gradually decreased, similar to lipid content. Conversely, in the cultures supplemented with $8.82 \mathrm{mM}$ of nitrogen, the protein content increased, while carbohydrate content reduced substantially compared to the initial value. The results confirm that this microalga accumulates carbohydrates under $\mathrm{N}$ deficient condition, as reported in a previous study (Kim et al. 2016a).

\section{Comparison of autotrophic and mixotrophic cultivation}

YE provides not only nitrogen but also organic carbon such as carbohydrate, thus, the cultivation using YE represents a mixotrophic condition. YE, which resulted in the highest lipid productivity, was selected to evaluate the feasibility of replacing whole F/2 nutrients with YE. For the evaluation, four different medium compositions were prepared: (1) ASW with only $\mathrm{NaNO}_{3}$, (2) ASW with whole $\mathrm{F} / 2$ nutrients (including $\mathrm{NaNO}_{3}$ ), (3) ASW with only $\mathrm{YE}$, and (4) ASW with YE and whole F/2 nutrients (excluding $\mathrm{NaNO}_{3}$ ).

When cells were grown in the autotrophic culture with only sodium nitrate, the lowest cell concentration of 1.1 $\mathrm{g} \mathrm{L}^{-1}$ and biomass productivity of $62.5 \mathrm{mg} \mathrm{L}^{-1} \mathrm{~d}^{-1}$ were obtained (Table 1, Fig. 4A); the remaining nitrogen levels in this culture was the highest from among the four different media (Fig. 4B). Nitrate as the sole nutrient source, did not support the cell growth, though the nitrogen was sufficient during the cultivation. When all nutrients of $\mathrm{F} / 2$ medium, including nitrate, phosphate, trace metals, and

Table 1. Comparison of biomass productivity, cellular lipid content, and lipid productivity under autotrophic / mixotrophic cultivation

\begin{tabular}{|c|c|c|c|c|}
\hline & Media composition & Biomass productivity $\left(\mathrm{g} \mathrm{L}^{-1} \mathrm{~d}^{-1}\right)$ & Lipid content (wt \%) & Lipid productivity (mg L $\left.{ }^{-1} d^{-1}\right)$ \\
\hline \multirow[t]{2}{*}{ Autotrophic } & $\mathrm{NaNO}_{3}$ & $62.5 \pm 3.5$ & $21.6 \pm 0.50$ & $15.8 \pm 0.31$ \\
\hline & $\mathrm{NaNO}_{3}+\mathrm{F} / 2$ & $105.0 \pm 0.0$ & $20.0 \pm 0.06$ & $22.5 \pm 0.08$ \\
\hline \multirow[t]{2}{*}{ Mixotrophic } & Yeast extract & $152.5 \pm 3.5$ & $19.6 \pm 0.21$ & $31.5 \pm 0.23$ \\
\hline & $\mathrm{YE}+\mathrm{F} / 2$ (without $\mathrm{NaNO}_{3}$ ) & $140.0 \pm 0.0$ & $23.2 \pm 0.28$ & $36.0 \pm 0.70$ \\
\hline
\end{tabular}

Values are presented as mean \pm standard deviation $(n=2)$.

Nitrogen concentrations were the same at $8.82 \mathrm{mM}$ in all culture. 

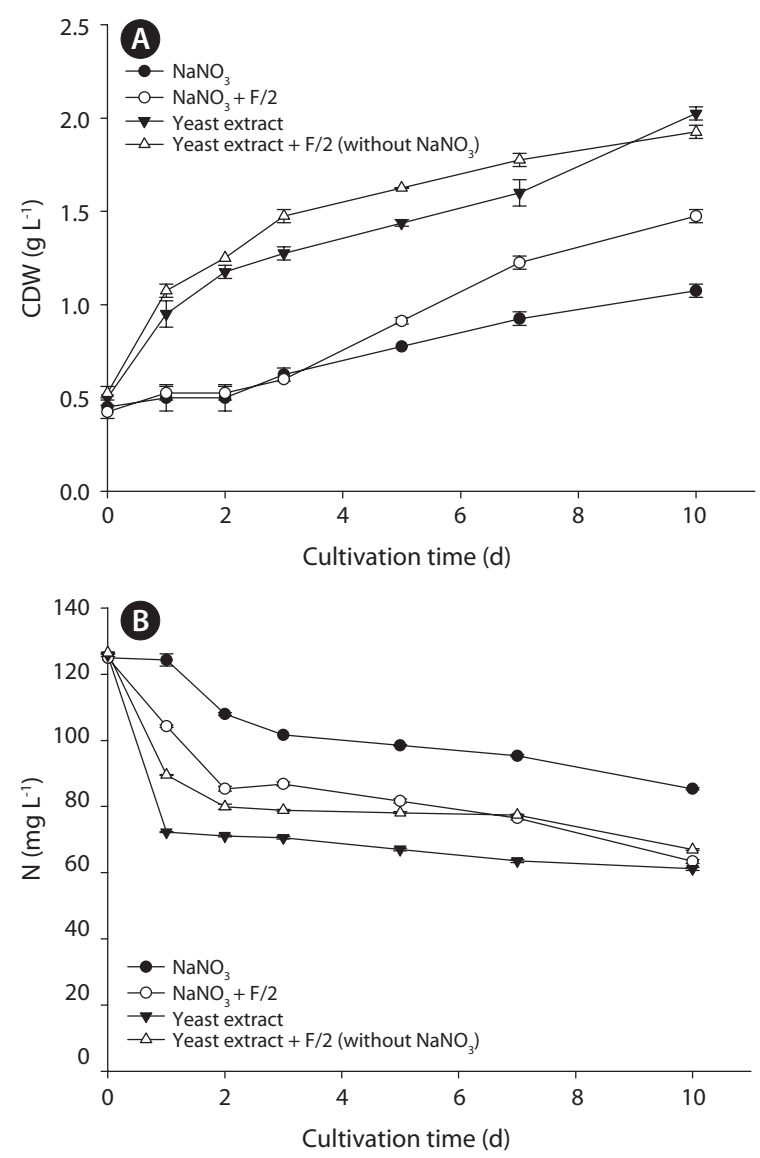

Fig. 4. Cell growth $(A)$ and nitrogen concentration remaining in the medium (B) under autotrophic / mixotrophic conditions. CDW, cell dry weight.

vitamins were supplemented, a higher cell concentration of $1.5 \mathrm{~g} \mathrm{~L}^{-1}$ and biomass productivity of $105.0 \mathrm{mg} \mathrm{L}^{-1} \mathrm{~d}^{-1}$ were achieved on the final day, indicating the supply of the additional nutrients affected the cell growth. On the other hand, in both mixotrophic cultures using YE with or without $\mathrm{F} / 2$ nutrients, the final cell concentrations were similar, showing an approximately 2 -fold higher value compared to that in autotrophic culture with $\mathrm{F} / 2$ medium. These results indicate that YE can solely support the cell growth of Tetraselmis sp. without any additional supplementation of F/2 nutrients. The lipid contents obtained on the final day from the four different media was not much different, ranging from 19.6-23.2\%. However, due to the big differences in biomass productivities, the resultant lipid productivity was higher in the mixotrophic cultures with YE than autotrophic cultures, as shown in Table 1. The lipid productivity in the culture with YE only was not the highest one, but it is still comparable to that in autotrophic cultures.

\section{Fatty acid profiles}

The major fatty acids were C16:0, C18:1, C18:2, and C18:3 (palmitic, oleic, linoleic, and linolenic acids), regardless of the medium composition (Table 2). The content of mono unsaturated fatty acids was similar in both media, but the culture with YE resulted in a lower content of poly unsaturated fatty acids (PUFA) than that with F/2 medium. In the culture with $\mathrm{F} / 2$ medium, linoleic acid (C18:2) and linolenic acid (C18:3) contents were higher, and stearic acid (C18:0) content was much lower than those in the culture with YE.

Fatty acid profile is an important factor that affects biodiesel properties, since the molecular characteristics of FAMEs, such as carbon chain length and the number of double bonds, directly influence the viscosity, ignition quality, oxidative stability, and cold flow property (Knothe 2009, Singh et al. 2014). Also, the fatty acid composition can be changed by various factors, including different nutritional conditions, physicochemical conditions, and growth phases (Mata et al. 2010, Kim and Hur 2013). Oxidation stability and cold flow performance are known to have inverse relationships to changes in fatty acids composition (Serrano et al. 2014). For example,

Table 2. Fatty acid composition of FAME biodiesel from the cells cultivated under autotrophic / mixotrophic cultures

\begin{tabular}{ccc}
\hline \multirow{2}{*}{ Fatty acids } & \multicolumn{2}{c}{ Fatty acids (\%) } \\
\cline { 2 - 3 } & $\begin{array}{c}\text { Autotrophic culture } \\
\text { with sodium nitrate }\end{array}$ & $\begin{array}{c}\text { Mixotrophic culture } \\
\text { with yeast extract }\end{array}$ \\
\hline C10:0 & $0.96 \pm 0.66$ & $3.60 \pm 0.26$ \\
C14:0 & $0.96 \pm 0.07$ & $1.79 \pm 0.30$ \\
C16:0 & $23.9 \pm 2.10$ & $24.40 \pm 1.09$ \\
C16:1 & $0.73 \pm 0.04$ & $1.16 \pm 0.31$ \\
C17:0 & $9.21 \pm 0.28$ & $6.33 \pm 0.48$ \\
C16:4 & $7.88 \pm 0.24$ & $6.64 \pm 0.55$ \\
C18:0 & $2.37 \pm 0.17$ & $11.55 \pm 0.53$ \\
C18:1 & $13.37 \pm 0.37$ & $13.18 \pm 0.85$ \\
C18:2 & $18.88 \pm 0.71$ & $13.08 \pm 0.24$ \\
C18:3 & $14.03 \pm 0.86$ & $11.77 \pm 0.79$ \\
C18:4 & $2.55 \pm 0.10$ & $1.80 \pm 0.07$ \\
C22:0 & $5.18 \pm 0.33$ & $4.70 \pm 0.16$ \\
SFA & 42.57 & 52.37 \\
UFA & 57.43 & 47.63 \\
MUFA & 14.10 & 14.34 \\
PUFA & 43.33 & 33.29 \\
\hline
\end{tabular}

Values are presented as mean \pm standard deviation $(n=3)$. Cells were harvested on the 10th day of cultivation.

FAME, fatty acid methyl esters; SFA, saturated fatty acids; UFA, unsaturated fatty acids; MUFA, mono unsaturated fatty acids; PUFA, poly unsaturated fatty acids. 
the increase in unsaturated fatty acids (UFAs) would improve the cold flow property, while reducing the oxidative stability. Conversely, increase of saturated fatty acids (SFAs) could result in better oxidative stability but poor cold flow property. Mixotrophic cultivation of Tetraselmis sp. can be advantageous in respect that higher oxidation stability could be obtained due to a lower PUFA content, than when cultured under autotrophic conditions. The presence of high fraction of UFA, including C18:2 and $\mathrm{C} 18: 3$, results in a low cetane number of biodiesel, causing a poor ignition quality (Lapuerta et al. 2009). Since the fraction of UFA is lower in mixotrophic culture, ignition quality would be better than that in autotrophic culture. Although higher fraction of SFA can result in an inferior cold-flow property, it is possible to meet the fuel quality by using some additives, such as a cold flow improver (Knothe 2009).

\section{CONCLUSION}

Microalga Tetraselmis sp. was found to efficiently utilize organic nitrogen sources, such as YE, glycine, and urea for cell growth. Between nitrate and ammonium, nitrate was clearly preferred for growth rather than ammonium, but a higher cellular lipid content was obtained from the culture with ammonium rather than nitrate on the final day of cultivation. Among nine different $\mathrm{N}$ sources, YE resulted in the highest lipid productivity, followed by urea and nitrate. When applying mass cultivation for biodiesel production, urea and nitrate would be more appropriate than YE in terms of economic feasibility. In the absence of nitrogen, Tetraselmis sp. significantly accumulated carbohydrate, reducing in fractions of protein and lipid. When the Tetraselmis sp. was cultivated in mixotrophic conditions with $\mathrm{YE}$, higher biomass productivity of $0.152 \mathrm{~g} \mathrm{~L}^{-1}$ and lipid productivity of $36.0 \mathrm{mg} \mathrm{L}^{-1} \mathrm{~d}^{-1}$ were achieved, compared to those in autotrophic conditions.

\section{ACKNOWLEDGEMENTS}

This research was supported by a grant from the Marine Biotechnology Program (PJT200255, Development of Marine Microalgal Biofuel Production Technology) funded by the Ministry of Oceans and Fisheries of Korea.

\section{REFERENCES}

American Public Health Association. 1995. Standard methods for the examination of water and wastewater. 19th ed. American Public Health Association, Washington, DC, 43 pp.

Bartley, M. L., Boeing, W. J., Daniel, D., Dungan, B. N. \& Schaub, T. 2016. Optimization of environmental parameters for Nannochloropsis salina growth and lipid content using the response surface method and invading organisms. J. Appl. Phycol. 28:15-24.

Becker, E. W. 1994. Microalgae biotechnology and microbiology. Cambridge University Press, New York, 18 pp.

Bligh, E. G. \& Dyer, W. J. 1959. A rapid method for total lipid extraction and purification. Can. J. Biochem. Physiol. 37:911-917.

Cai, T., Park, S. Y. \& Li, Y. 2013. Nutrient recovery from wastewater streams by microalgae: status and prospects. Renew. Sustain. Energy Rev. 19:360-369.

Campos, H., Boeing, W. J., Dungan, B. N. \& Schaub, T. 2014. Cultivating the marine microalga Nannochloropsis salina under various nitrogen sources: effect on biovolume yields, lipid content and composition, and invasive organisms. Biomass Bioenergy 66:301-307.

Chen, M., Tang, H., Ma, H., Holland, T. C., Ng, K. Y. \& Salley, S. O. 2011. Effect of nutrients on growth and lipid accumulation in the green algae Dunaliella tertiolecta. Bioresour. Technol. 102:1649-1655.

Dubois, M., Gilles, K. A., Hamilton, J. K., Rebers, P. A. \& Smith, F. 1956. Colorimetric method for determination of sugars and related substances. Anal. Chem. 28:350-356.

Ferreira, L. S., Rodrigues, M. S., Converti, A., Sato, S. \& Carvalho, J. C. M. 2010. A new approach to ammonium sulphate feeding for fed-batch Arthrospira (Spirulina) platensis cultivation in tubular photobioreactor. Biotechnol. Prog. 26:1271-1277.

Fidalgo, J. P., Cid, A., Torres, E., Sukenik, A. \& Herrero, C. 1998. Effects of nitrogen source and growth phase on proximate biochemical composition, lipid classes and fatty acid profile of the marine microalga Isochrysis galbana. Aquaculture 166:105-116.

Gu, H., Nagle, N., Pienkos, P. T. \& Posewitz, M. C. 2015. Nitrogen recycling from fuel-extracted algal biomass: residuals as the sole nitrogen source for culturing Scenedesmus acutus. Bioresour. Technol. 184:153-160.

Guillard, R. R. L. 1975. Culture of phytoplankton for feeding marine invertebrates. In Smith, W. L. \& Chanley, M. H. (Eds.) Culture of Marine Invertebrate Animals. Plenum Press, New York, pp. 26-60.

Ho, S. -H., Ye, X., Hasunuma, T., Chang, J. -S. \& Kondo, A. 
2014. Perspectives on engineering strategies for improving biofuel production from microalgae: a critical review. Biotechnol. Adv. 32:1448-1459.

$\mathrm{Hu}, \mathrm{Q}$. 2013. Environmental effects on cell composition. In Richmond, A. \& Hu, Q. (Eds.) Handbook of Microalgal Culture: Applied Phycology and Biotechnology. 2nd ed. Wiley Blackwell, West Sussex, pp. 114-122.

Huang, C. -C., Hung, J. -J., Peng, S. -H. \& Chen, C. -N. N. 2012. Cultivation of a thermos-tolerant microalga in an outdoor photobioreactor: influences of $\mathrm{CO}_{2}$ and nitrogen sources on the accelerated growth. Bioresour. Technol. 112:228-233.

Kim, D. G. \& Hur, S. B. 2013. Growth and fatty acid composition of three heterotrophic Chlorella species. Algae 28:101-109.

Kim, G., Bae, J. \& Lee, K. 2016a. Nitrate repletion strategy for enhancing lipid production from marine microalga Tetraselmis sp. Bioresour. Technol. 205:274-279.

Kim, G., Lee, C. -H. \& Lee, K. 2016b. Enhancement of lipid production in marine microalga Tetraselmis sp. through salinity variation. Korean J. Chem. Eng. 33: 230-237.

Kim, G., Mujtaba, G., Rizwan, M. \& Lee, K. 2014. Environmental stress strategies for stimulating lipid production from microalgae for biodiesel. Appl. Chem. Eng. 25:553-558.

Kim, Z. -H., Park, H., Hong, S. -J., Lim, S. -M. \& Lee, C. -G. 2016c. Development of a floating photobioreactor with internal partitions for efficient utilization of ocean wave into improved mass transfer and algal culture mixing. Bioprocess Biosyst. Eng. 39:713-723.

Knothe, G. 2009. Improving biodiesel fuel properties by modifying fatty ester composition. Energy Environ. Sci. 2:759-766.

Konig, A., Pearson, H. W. \& Silva, S. A. 1987. Ammonia toxicity to algal growth in waste stabilization ponds. Water Sci. Technol. 19:115-122.

Kumar, V., Muthuraj, M., Palabhanvi, B., Ghoshal, A. K. \& Das, D. 2014. High cell density lipid rich cultivation of a novel microalgal isolate Chlorella sorokiniana FC6 IITG in a single-stage fed-batch mode under mixotrophic condition. Bioresour. Technol. 170:115-124.

Lapuerta, M., Rodríguez-Fernández, J. \& de Mora, E. F. 2009. Correlation for the estimation of the cetane number of biodiesel fuels and implications on the iodine number. Energy Policy 37:4337-4344.

Lee, C. G., Seong, D. H., Yim, S. M. \& Bae, J. H. 2015. A novel Tetraselmis sp. and method for preparing biodiesel with this strain. Korean Patent 10-1509562.

Li, T., Zheng, Y., Yu, L. \& Chen, S. 2013. High productivity cultivation of a heat-resistant microalga Chlorella sorokiniana for biofuel production. Bioresour. Technol. 131:6067.
Li, Y., Horsman, M., Wang, B., Wu, N. \& Lan, C. Q. 2008. Effects of nitrogen sources on cell growth and lipid accumulation of green alga Neochloris oleoabundans. Appl. Microbiol. Biotechnol. 81:629-636.

Lourenço, S. O., Barbarino, E., Mancini-Filho, J., Schinke, K. P. \& Aidar, E. 2002. Effects of different nitrogen sources on the growth and biochemical profile of 10 marine microalgae in batch culture: an evaluation for aquaculture. Phycologia 41:158-168.

Lowry, O. H., Rosebrough, N. J., Farr, A. L. \& Randall, R. J. 1951. Protein measurement with the Folin phenol reagent. J. Biol. Chem. 193:265-275.

Mata, T. M., Martins, A. A. \& Caetano, N. S. 2010. Microalgae for biodiesel production and other applications: a review. Renew. Sustain. Energy Rev. 14:217-232.

Muthuraj, M., Kumar, V., Palabhanvi, B. \& Das, D. 2014. Evaluation of indigenous microalgal isolate Chlorella sp. FC2 IITG as a cell factory for biodiesel production and scale up in outdoor conditions. J. Ind. Microbiol. Biotechnol. 41:499-511.

Norici, A., Dalsass, A. \& Giordano, M. 2002. Role of phosphoenolpyruvate carboxylase in anaplerosis in the green microalga Dunaliella salina cultured under different nitrogen regimes. Physiol. Plant. 116:186-191.

Podevin, M., De Francisci, D., Holdt, S. L. \& Angelidaki, I. 2015. Effect of nitrogen source and acclimatization on specific growth rates of microalgae determined by a high-throughput in vivo microplate autofluorescence method. J. Appl. Phycol. 27:1415-1423.

Ramanna, L., Guldhe, A., Rawat, I. \& Bux, F. 2014. The optimization of biomass and lipid yields of Chlorella sorokiniana when using wastewater supplemented with different nitrogen sources. Bioresour. Technol. 168:127-135.

Roopnarain, A., Sym, S. \& Gray, V. M. 2015. Effect of nitrogenous resource on growth, biochemical composition and ultrastructure of Isochrysis galbana (Isochrysidales, Haptophyta). Phycol. Res. 63:43-50.

Ruangsomboon, S. 2015. Effects of different media and nitrogen sources and levels on growth and lipid of green microalga Botryococcus braunii KMITL and its biodiesel properties based on fatty acid composition. Bioresour. Technol. 191:377-384.

Sassano, C. E. N., Gioielli, L. A., Almeida, K. A., Sato, S., Perego, P., Coverti, A. \& Carvalho, J. C. M. 2007. Cultivation of Spirulina platensis by continuous process using ammonium chloride as nitrogen source. Biomass Bioenergy 31:593-598.

Serrano, M., Oliveros, R., Sánchez, M., Moraschini, A., Martínez, M. \& Aracil, J. 2014. Influence of blending vegetable oil methyl esters on biodiesel fuel properties: 
oxidative stability and cold flow properties. Energy 65:109-115.

Singh, B., Guldhe, A., Rawat, I. \& Bux, F. 2014. Towards a sustainable approach for development of biodiesel from plant and microalgae. Renew. Sustain. Energy Rev. 29:216-245.

Solomon, C. M. \& Glibert, P. M. 2008. Urease activity in five phytoplankton species. Aquat. Microb. Ecol. 52:149-157.

Van Wychen, S., Ramirez, K. \& Laurens, L. M. L. 2013. Determination of total lipids as fatty acid methyl esters (FAME) by in situ transesterification. Laboratory Analytical Procedure. National Renewable Energy Laboratory, Golden, CO, $12 \mathrm{pp}$.

Wan, M. -X., Wang, R. -M., Xia, J. -L., Rosenberg, J. N., Nie, Z. -Y., Kobayashi, N., Oyler, G. A. \& Betenbaugh, M. J. 2012. Physiological evaluation of a new Chlorella sorokiniana isolate for its biomass production and lipid accumula- tion in photoautotrophic and heterotrophic cultures. Biotechnol. Bioeng. 109:1958-1964.

Wang, J., Sommerfeld, M. R., Lu, C. \& Hu, Q. 2013. Combined effect of initial biomass density and nitrogen concentration on growth and astaxanthin production of Haematococcus pluvialis (Chlorophyta) in outdoor cultivation. Algae 28:193-202.

Wu, L. F., Chen, P. C. \& Lee, C. M. 2013. The effects of nitrogen sources and temperatures on cell growth and lipid accumulation of microalgae. Int. Biodeterior. Biodegrad. 85:506-510.

Yen, H. W., Hu, I. C., Chen, C. Y. \& Chang, J. S. 2014. Design of photobioreactors for algal cultivation. In Pandey, A., Lee, D. -J., Chisti, Y. \& Soccol, C. R. (Eds.) Biofuels from Algae. Elsevier, San Diego, CA, pp. 23-45.

Zhu, C. J. \& Lee, Y. K. 1997. Determination of biomass dry weight of marine microalgae. J. Appl. Phycol. 9:189-194. 